\title{
Draftbility of Power Tiller with Different Lug Angle of Cage Wheels in Puddle Soils for Paddy
}

\author{
Piyush Pradhan ${ }^{1 *}$, A. K. Verma ${ }^{1}$, R. K. Naik ${ }^{1}$ and P. K. Guru ${ }^{2}$ \\ ${ }^{1}$ Dept. of Farm Machinery and Power Engineering, SVCAET and RS Faculty of Agricultural Engineering, \\ IGKV Raipur, C.G. (492 012), India \\ ${ }^{2}$ Central Rice Research Institute, Cuttack, Orissa (753 006), India
}

\section{Corresponding Author}

Piyush Pradhan

e-mail: piyushpradhan202@gmail.com

\author{
Article History \\ Manuscript No. AR1766 \\ Received in $2^{\text {nd }}$ Jan, 2017 \\ Received in revised form $7^{\text {th }}$ Feb, 2017 \\ Accepted in final form $7^{\text {th }}$ Feb, 2017
}

\begin{abstract}
The experiment was conducted on IGKV research farm in wet puddle condition in April month of 2015. The wet tillage practice was carried out by power tiller cage wheel attached with five tines cultivator. Paddy production increases by puddling of soil before transplanting. Cage wheel is an important traction device for any prime mower. The lug is wing provided in cage wheels which interact with the wet soil to churn the soil .The cage wheel $730 \mathrm{~mm}$ diameter with $30^{\circ}, 45^{\circ}$, and $60^{\circ}$ lug angle and three different diameter of $73 \mathrm{~mm}, 680 \mathrm{~mm}$ and $780 \mathrm{~mm}$ of $30^{\circ}$ was tested at 0 to $50 \mathrm{~mm}, 50$ to $100 \mathrm{~mm}, 100$ to $150 \mathrm{~mm}$ and 150 to $200 \mathrm{~mm}$, depth of water level in wet land field. The result was found that cage wheel $\mathrm{C} 1$ of $30^{\circ}$ lug angle with $730 \mathrm{~mm}$ diameter give better performance than other cage wheel. The cage wheel showed the best result in 50-100 mm water level in respect to maximum tractive efficiency was found in the range of $73-78 \%$ at $996 \mathrm{~N}$ to $1009 \mathrm{~N}$ draft and drawbar power was in the range of $478.08 \mathrm{~W}$ to $484.32 \mathrm{~W}$. While maximum drawbar power was ( 523.16 to $555.28 \mathrm{~W}$ ) was observed at 0 to $50 \mathrm{~mm}$ water level. Therefore cage wheel of $30^{\circ}$ lug angle with $730 \mathrm{~mm}$ diameter was found suitable for wet land paddy field condition.
\end{abstract}

Keywords: Cage, lug angle, draft, drawbar power, tractive efficiency

\section{Introduction}

Power tiller is a low horse power walking type tractor where the operator trails behind the machine, holding two handle of tiller also seat is provided in some design. Technological improvement in Indian agriculture through the mechanization from last sixties year come revolution in agriculture production. The timeliness of operations has assumed greater significant in obtaining optimal yields from different crops, which has been possible by way of mechanization (Singh, 2007). Contribution of tractors and power tillers was only $2.54 \%$ of the total farm power in 1960-61 increased to about 50\% in 2013-14 in this period tractor population in India has grown from 0.037 million to 5.237 million units at an annual compound growth rate of about 10 per cent during the last 53 years (Singh et al., 2010). Application of a drawbar load improves the performance of lighter tractors on wet soil because it increases the driving axle load by the effect of weight transfer (Baloch et al., 1991). Cage wheel is the important traction device for wet land field. The lugs of the cage wheel are the basic elements to interact with the wet soil. Rice production calendar generally includes the period of soil puddling and transplanting of rice seedling processes in which rice field soils are in flooded or slurry-like condition. At this period, farm vehicles have to struggle with severe loss of their mobility even in the field with appropriate hardpan. Cage wheel using fixed lugs also have a soil blocking problem among the lugs when operated paddy soil and using open, flat-lugged wheels for a small power tiller operated on agricultural soils, it was observed that the cross-sectional area of blocked soil (i.e. amounts of soil wedge) became smaller when the lug angle was increased reported by Triratanasirichai et al. (1990). soil adhesion plays a significant role for soil sticking on cage wheel lugs as reported by Salokhe and GeeClough (1988a), they found later that a coating of lug surfaces with teflon tape, ceramic tile and enamel did not affect the lug forces. Rizaldi et al. (2014) Tested lug wheel with $42 \mathrm{~cm}$ in diameter and varying numbers of lug which were 8,10 , and 12 lugs, respectively Lug angle was varied from $30^{\circ}, 35^{\circ}$ and $40^{\circ}$ and found that the smallest tractive efficiency, about $21.91 \%$, was obtained when a 10 lug wheel was used with lug angle $40^{\circ}$. The highest efficiency was obtained when the lug wheel has 12 lugs with lug angle $30^{\circ}$, which was about $34.62 \%$. The top layer of wet soil has low shear strength so that sufficient thrust cannot be developed Abubakar et al. (2009). Salokhe and Gee-Clough (1988) observed that cage wheels ranging smaller diameter of the drive wheel should be fitted to tractors. Arvind and Baruah (2016) experimented over two lug plates, each set of lugs were fitted on cage wheel frame at 450 
angular spacing for testing its field performance at two levels of soil moisture contents ( $23 \%$ and $36 \%$ ). Split lug cage wheel fitted power tiller operation resulted about $27 \%$ less wheel slip associated with about $14 \%$ saving of fuel $\left(\mathrm{ha}^{-1}\right)$ in comparison of non-split lug in moist field. The forces under a single cage wheel lug were measured by and Salokhe et al. (1990a). They observed that the forces under a single cage wheel lug were affected by lug sinkage and soil moisture content. These cage wheels give high traction, support the vehicle by distributing the weight of the machine over as great an area as possible, reduce soil compaction and prevent it from bogging down.

\section{Material and Methods}

The field experiments were conducted at the research farm of SVCAET and RS Faculty of Agricultural Engineering, IGKV, Raipur (C.G.), India in April, 2015. The implement, cage wheel for power tiller was fabricated in the faculty work shop. The testing and performance evaluation of different cage wheel in terms of tillage, tractive power, drawbar power in wetland condition, attached with five tynes of cultivator of power tiller. The designed dimensions and drawings were prepared by using the solid works software. The selection of materials and fabrication were done following the standard manufacturing procedures. Different part of cage wheel were described in Figure 1.

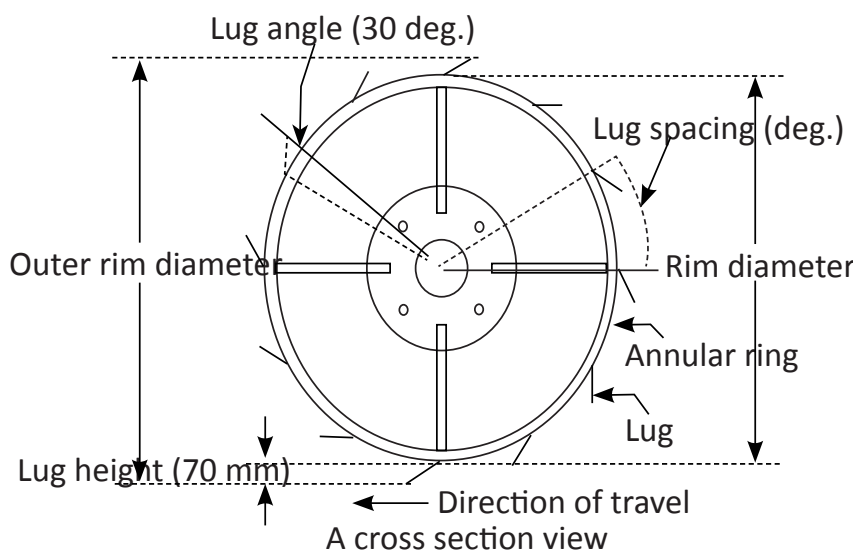

Figure 1: Sketch of cage wheel describing different parameters

\subsection{Experimental details}

A simulation study was done by solid works analysis for FEA to know the stress and strain effect on the different part of cage wheel. The wet land operation was carried out with power tiller with Beausani implement at different depth of water level of 0 to $50 \mathrm{~mm}, 50$ to $100 \mathrm{~mm}, 100$ to $150 \mathrm{~mm}$ and 150 to $200 \mathrm{~mm}$ in field condition. Three types of cage wheel in which three different lug angle of cage wheel was tested Figure 2.

Drawbar power was calculated by using following formula $\mathrm{DP}=\frac{\mathrm{P} \times \mathrm{V}}{1000} \ldots \ldots . .1$

Where,

$\mathrm{Dp}=$ Drawbar power $(\mathrm{kW})$,

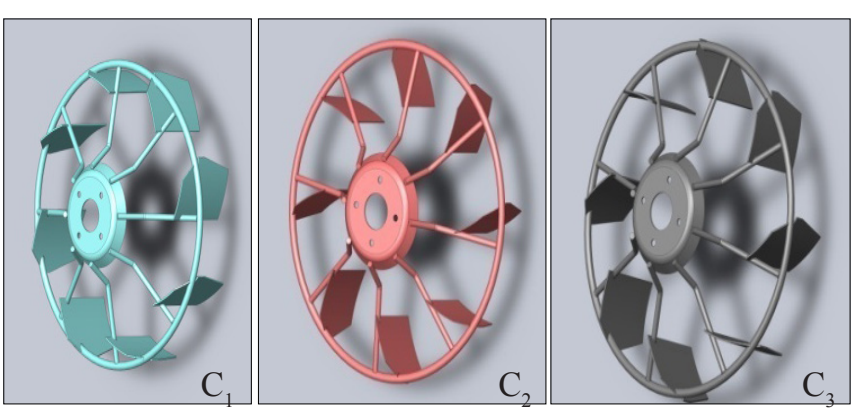

Figure 2: Cage wheel of different lug angle $C_{1}\left(30^{\circ}\right), C_{2}\left(45^{\circ}\right)$ and $\mathrm{C}_{3}\left(60^{\circ}\right)$

$\mathrm{V}=$ actual forward speed (with load) (m/s), and

$\mathrm{P}=$ pull generated $(\mathrm{N})$.

Tractive efficiency was calculated by following formula

Tractive efficiency $=\frac{\text { Drawbar power }}{\text { Axle power }}$.........2

Where,

Drawbar power $\mathrm{W}=\mathrm{draft}(\mathrm{N}) \times$ forward speed $(\mathrm{m} / \mathrm{s})$, and

Axle power=torque $(\mathrm{N}-\mathrm{m}) \times$ wheel revolution $\omega(\mathrm{rad} / \mathrm{s})$.

\subsection{Power tiller and wet tillage implements}

A $9.69 \mathrm{~kW}$ power tiller was used to test the drawbar performance and tractive performance on a wet land field attached with five tynes cultivator with cage wheel having different lug angle. A total mass of $54 \mathrm{~kg}(27 \mathrm{~kg}$ on each wheel) was mounted on the sides of the wheels to study its effect on draft, drawbar power and tractive efficiency. The fuel consumption was measured with a burette mounted at the front portion of the power tiller. The specifications of cage wheel were described on below in Table 1.

Table 1: specification of cage wheels

Table 1: specification of cage wheels

\begin{tabular}{|c|c|c|c|c|}
\hline $\begin{array}{l}\text { Sl. } \\
\text { No. }\end{array}$ & Parameter & $\begin{array}{c}\text { Cage } \\
\text { wheel } \\
\mathrm{C}_{1} \\
\end{array}$ & $\begin{array}{c}\text { Cage } \\
\text { wheel } \\
\mathrm{C}_{2}\end{array}$ & $\begin{array}{c}\text { Cage } \\
\text { wheel } \\
\mathrm{C}_{3} \\
\end{array}$ \\
\hline 1. & Wheel diameter (mm) & 730 & 730 & 730 \\
\hline 2. & Wheel width (mm) & 300 & 300 & 300 \\
\hline 3. & No of lugs & 8 & 8 & 8 \\
\hline 4. & Lug width (mm) & 161 & 161 & 161 \\
\hline 5. & Lug length (mm) & 215 & 215 & 215 \\
\hline 6. & Lug angle $\left({ }^{\circ}\right)$ & 30 & 45 & 60 \\
\hline 7. & Lug pitch (mm) & 204 & 204 & 204 \\
\hline 8. & Lug thickness (mm) & 4 & 4 & 4 \\
\hline 9. & Ring thickness (mm) & 20 & 20 & 20 \\
\hline 10. & $\begin{array}{l}\text { Supportive rod thickness } \\
(\mathrm{mm})\end{array}$ & 15 & 15 & 15 \\
\hline 11. & Supportive rod length (mm) & 279 & 279 & 279 \\
\hline
\end{tabular}




\section{Result and Discussion}

3.1. Effect of lug angle on drawbar power and tractive performance at 0 to $50 \mathrm{~mm}$ depth of water

Drawbar power at different lug angle of cage wheel on wet land condition is shown in Figure 3. It was found that increase

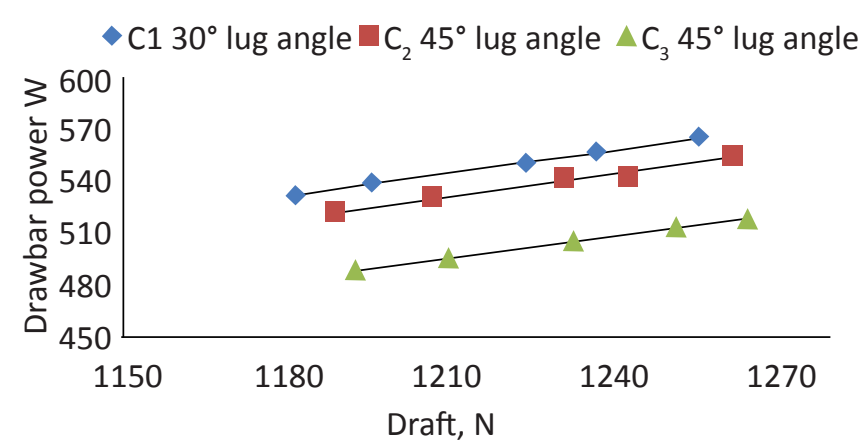

Figure 3: Effect of draft on drawbar power at 0 to $50 \mathrm{~mm}$ depth of water level

the drawbar power as increasing of draft and slippage. The maximum drawbar power $565.20 \mathrm{~W}$ was found for cage wheel $C_{1}$ followed by for $C_{2}(555.28 \mathrm{~W})$ and $C_{3}(518.65 \mathrm{~W})$ for cage wheel. Maximum draft was found $1265 \mathrm{~N}$ for cage wheel $C_{3}$ than the $C_{1}$ and $C_{2}$. From (Table 2) it was found that increasing lug angle drawbar power reduced. The similar results were reported by Anonymous (1975). Figure 4 shows the relationship between tractive efficiency between efficiency

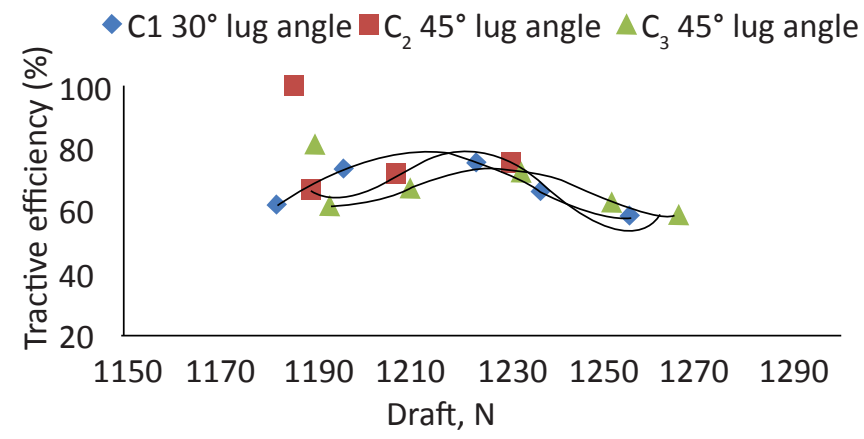

Figure 4: Effect of draft on tractive performance at 0 to 50 $\mathrm{mm}$ water level and draft at different lug angles of cage wheel on wet land condition. The results found that the lug angles significantly affect the tractive efficiency. Results indicate that as the draft increases tractive power increases till a maximum point than further decreases. The maximum tractive efficiency was observed $75.90 \%$ with draft $1224 \mathrm{~N}$ at $10.56 \%$ slippage for $30^{\circ}$ lug angle for cage wheel $\mathrm{C}_{1}$. It was also revealed from the study that as draft increases, working speed reduced due to increase in sinkage and slippage. The maximum tractive efficiency $75.54 \%$ for cage wheel $C_{2}$ at $1231 \mathrm{~N}$ whereas, minimum tractive efficiency was observed $58.55 \%$ for cage wheel $\mathrm{C}_{3}$ at $15 \%$ wheel slippage with $1265 \mathrm{~N}$ draft (Table 2). The similar results were reported by Triratanasirichai (1990).

\subsection{Effect of lug angle on drawbar power and tractive} performance at 50 to $100 \mathrm{~mm}$ depth of water

Increase in standing water level from 0 to 50 to 50 to $100 \mathrm{~mm}$, draft was reduced but tractive efficiency increases. Maximum drawbar power was found $531.96 \mathrm{~W}$ at $1023 \mathrm{~N}$ draft for cage wheel $\mathrm{C}_{1}$ followed by $492.96 \mathrm{~W}$ and $476.56 \mathrm{~W}$ for cage wheel $\mathrm{C}_{2}$ and $\mathrm{C}_{3}$ with $1036 \mathrm{~N}$ and $1027 \mathrm{~N}$ draft respectively (Table 3). Increase in draft resulted increases in drawbar power as shown in Figure 5. Increase in water level, reduces, wheel slippage and sinkage that causes reduce in depth of ploughing that causes minimum draft. Tractive efficiency was observed at 50 to $100 \mathrm{~mm}$ depth of water level as given in (Table 3). Maximum tractive efficiency $78.72 \%$ was obtained at draft

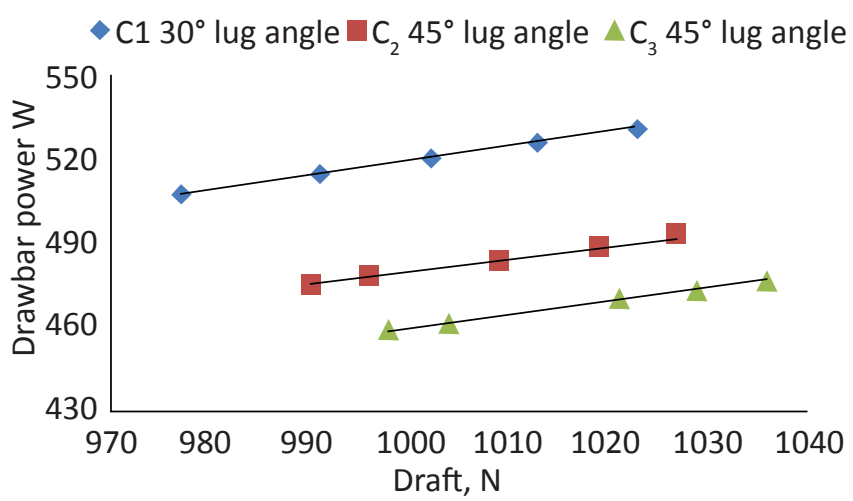

Figure 5: Effect of draft on drawbar power at 50 to $100 \mathrm{~mm}$ water

\begin{tabular}{|c|c|c|c|c|c|c|c|c|c|}
\hline \multirow{2}{*}{$\begin{array}{l}\text { Cage } \\
\text { wheel } \\
\text { Sl. No. }\end{array}$} & \multicolumn{3}{|c|}{$\mathrm{C}_{1} 30^{\circ}$ lug angle } & \multicolumn{3}{|c|}{$\mathrm{C}_{2} 45^{\circ}$ lug angle } & \multicolumn{3}{|c|}{$\mathrm{C}_{3} 60^{\circ}$ lug angle } \\
\hline & $\begin{array}{l}\text { Draft } \\
(\mathrm{N})\end{array}$ & $\begin{array}{c}\text { Drawbar } \\
\text { power (W) }\end{array}$ & $\begin{array}{l}\text { Tractive ef- } \\
\text { ficiency (\%) }\end{array}$ & $\begin{array}{l}\text { Draft } \\
\text { (N) }\end{array}$ & $\begin{array}{c}\text { Drawbar } \\
\text { power (W) }\end{array}$ & $\begin{array}{l}\text { Tractive ef- } \\
\text { ficiency (\%) }\end{array}$ & $\begin{array}{l}\text { Draft } \\
(\mathrm{N})\end{array}$ & $\begin{array}{c}\text { Drawbar } \\
\text { power (W) }\end{array}$ & $\begin{array}{c}\text { Tractive } \\
\text { efficiency (\%) }\end{array}$ \\
\hline 1. & 1182 & 531.9 & 61.82 & 1189 & 523.16 & 66.88 & 1193 & 489.13 & 61.72 \\
\hline 2. & 1196 & 538.20 & 73.27 & 1207 & 531.08 & 71.42 & 1210 & 496.10 & 67.54 \\
\hline 3. & 1224 & 550.80 & 75.90 & 1231 & 541.64 & 75.54 & 1233 & 505.53 & 73.02 \\
\hline 4. & 1237 & 556.65 & 66.54 & 1243 & 542.92 & 62.65 & 1252 & 513.32 & 63.07 \\
\hline 5. & 1256 & 565.20 & 58.18 & 1262 & 555.28 & 59.01 & 1265 & 518.65 & 58.55 \\
\hline
\end{tabular}




\begin{tabular}{|c|c|c|c|c|c|c|c|c|c|}
\hline \multirow{2}{*}{$\begin{array}{l}\begin{array}{l}\text { Cage } \\
\text { wheel }\end{array} \\
\text { SI. No }\end{array}$} & \multicolumn{3}{|c|}{$\mathrm{C}_{1} 30^{\circ}$ lug angle } & \multicolumn{3}{|c|}{$\mathrm{C}_{2} 45^{\circ}$ lug angle } & \multicolumn{3}{|c|}{$\mathrm{C}_{3} 60^{\circ}$ lug angle } \\
\hline & $\begin{array}{l}\text { Draft } \\
(\mathrm{N})\end{array}$ & $\begin{array}{c}\text { Drawbar } \\
\text { power (W) }\end{array}$ & $\begin{array}{c}\text { Tractive } \\
\text { efficiency (\%) }\end{array}$ & $\begin{array}{l}\text { Draft } \\
\text { (N) }\end{array}$ & $\begin{array}{c}\text { Drawbar } \\
\text { power (W) }\end{array}$ & $\begin{array}{c}\text { Tractive } \\
\text { efficiency (\%) }\end{array}$ & $\begin{array}{l}\text { Draft } \\
(\mathrm{N})\end{array}$ & $\begin{array}{c}\text { Drawbar } \\
\text { power (W) }\end{array}$ & $\begin{array}{c}\text { Tractive } \\
\text { efficiency (\%) }\end{array}$ \\
\hline 1. & 977 & 508.04 & 70.01 & 990 & 475.20 & 67.06 & 998 & 459.08 & 64.02 \\
\hline 2. & 991 & 515.32 & 73.58 & 996 & 478.08 & 71.44 & 1004 & 461.84 & 69.46 \\
\hline 3. & 1002 & 521.04 & 78.72 & 1009 & 484.32 & 74.75 & 1021 & 469.68 & 73.30 \\
\hline 4. & 1013 & 526.76 & 65.89 & 1019 & 489.12 & 63.34 & 1029 & 473.34 & 62.87 \\
\hline 5. & 1023 & 531.96 & 62.10 & 1027 & 492.96 & 60.56 & 1036 & 476.56 & 60.13 \\
\hline
\end{tabular}

$1002 \mathrm{~N}$ for cage wheel $\mathrm{C}_{1}$ followed by $74.79 \%$ at $1009 \mathrm{~N}$ and $73.30 \%$ at $1023 \mathrm{~N}$ draft. It was observed that as draft increases tractive power increases up to maximum value

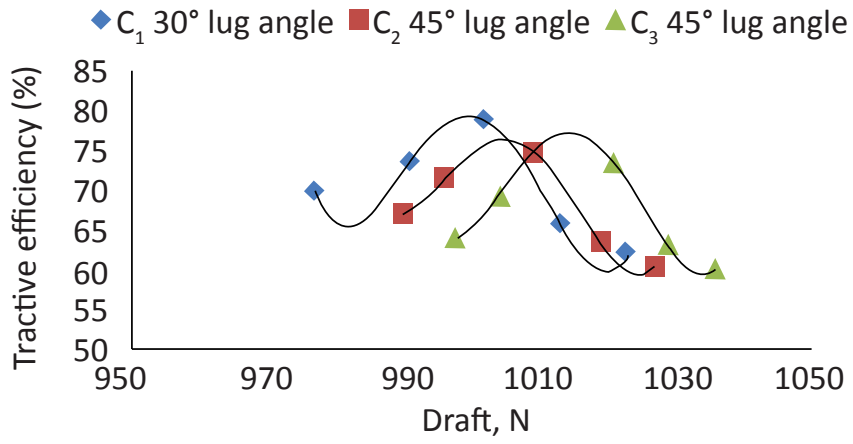

Figure 6: Effect of draft on tractive performance at 50 to 100 $\mathrm{mm}$ water

than it further decreases as shown in Figure 6. The minimum tractive efficiency was observed $60.13 \%$ for cage wheel $C_{3}$ than followed by $60.56 \%$ and $62.96 \%$ for cage wheels $C_{2}$ and $C_{1}$. Triratanasirichai et al. (1990) studied of $35^{\circ}$ lug angle and 14 lugs in puddled paddy field and they found the maximum tractive efficiency and wheel slip at the maximum tractive efficiency obtained in this study were these values to be 79 and $25 \%, 68$ and $40-50 \%$, and 49.2 and $40.1 \%$ respectively in wet clay soils. From this study, it was also revealed that, at the maximum tractive efficiency, the sinkage was high $(277 \mathrm{~mm}$ ) and maximum drawbar power was only $110 \mathrm{~W}$.

3.3. Effect of lug angle on drawbar power and tractive performance at 100 to $150 \mathrm{~mm}$ depth of water

Different lug angle of cage wheel was operated at 100 to $150 \mathrm{~mm}$ water level. The obtained value of drawbar power presented in (Table 4).The results indicate that as draft increases drawbar power also increases which depend on the wheel slippage, sinkage, sticking and depth of ploughing as shown in Figure 7. Maximum drawbar power was obtained $505.69 \mathrm{~W}$ at $829 \mathrm{~N}$ draft for cage wheel $\mathrm{C}_{1}$ which followed by $483.14 \mathrm{~W}$ at $833 \mathrm{~N}$ and $453.56 \mathrm{~W}$ at $840 \mathrm{~N}$ draft for $\mathrm{C}_{2}$ and $\mathrm{C}_{3}$ respectively. The minimum drawbar power was found 429.84 $\mathrm{W}$ for cage wheel $\mathrm{C}_{3}$ at $796 \mathrm{~N}$ draft. The similar results were

$\bullet \mathrm{C}_{1} 30^{\circ}$ lug angle $\mathrm{C}_{2} 45^{\circ}$ lug angle $\triangle \mathrm{C}_{3} 45^{\circ}$ lug angle

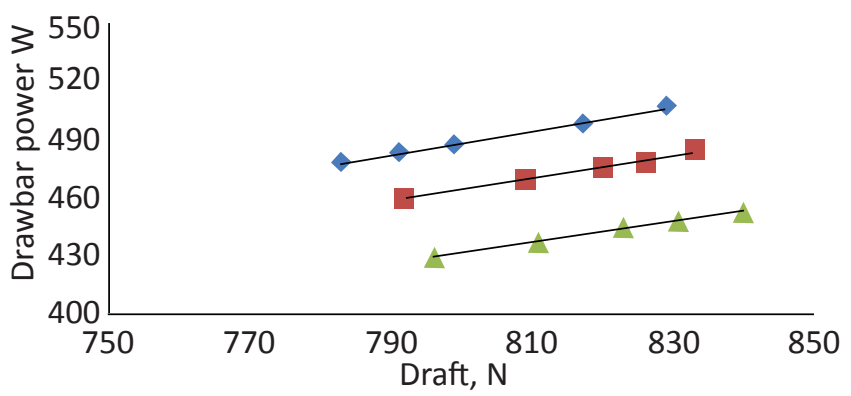

Figure 7: Effect of draft on drawbar power at 100 to $150 \mathrm{~mm}$ depth of water

\begin{tabular}{|c|c|c|c|c|c|c|c|c|c|}
\hline \multirow{2}{*}{$\begin{array}{l}\text { Cage } \\
\text { wheel } \\
\text { SI. No }\end{array}$} & \multicolumn{3}{|c|}{$\mathrm{C}_{1} 30^{\circ}$ lug angle } & \multicolumn{3}{|c|}{$\mathrm{C}_{2} 45^{\circ}$ lug angle } & \multicolumn{3}{|c|}{$\mathrm{C}_{3} 60^{\circ}$ lug angle } \\
\hline & $\begin{array}{l}\text { Draft } \\
\text { (N) }\end{array}$ & $\begin{array}{c}\text { Drawbar } \\
\text { power (W) }\end{array}$ & $\begin{array}{l}\text { Tractive ef- } \\
\text { ficiency (\%) }\end{array}$ & $\begin{array}{l}\text { Draft } \\
(\mathrm{N})\end{array}$ & $\begin{array}{c}\text { Drawbar } \\
\text { power (W) }\end{array}$ & $\begin{array}{l}\text { Tractive ef- } \\
\text { ficiency (\%) }\end{array}$ & $\begin{array}{l}\text { Draft } \\
\text { (N) }\end{array}$ & $\begin{array}{c}\text { Drawbar } \\
\text { power (W) }\end{array}$ & $\begin{array}{c}\text { Tractive effi- } \\
\text { ciency (\%) }\end{array}$ \\
\hline 1. & 783 & 477.63 & 63.44 & 792 & 459.36 & 61.78 & 796 & 429.84 & 62.09 \\
\hline 2. & 791 & 482.51 & 73.70 & 809 & 469.22 & 66.22 & 811 & 437.94 & 64.71 \\
\hline 3. & 799 & 487.29 & 77.05 & 820 & 475.60 & 71.07 & 823 & 444.42 & 73.79 \\
\hline 4. & 817 & 498.37 & 62.88 & 826 & 479.08 & 63.63 & 831 & 448.74 & 61.84 \\
\hline 5. & 829 & 505.69 & 59.61 & 833 & 483.14 & 56.15 & 840 & 453.60 & 58.74 \\
\hline
\end{tabular}


reported by Pandey and Ojha (1978). Increase in standing water level, increases tractive efficiency due to less sticking of soil on lug surface, easy to cut the soil, less slippage in wet land operation. The maximum tractive efficiency was found $77.05 \%$ for cage wheel $C_{1}$ at draft of 799 while $73.79 \%$ and $71.07 \%$ for $\mathrm{C}_{3}$ and $\mathrm{C}_{2}$ at $823 \mathrm{~N}$ and $820 \mathrm{~N}$ respective as shown in (Table 4). It was observed that as lug angle increases tractive

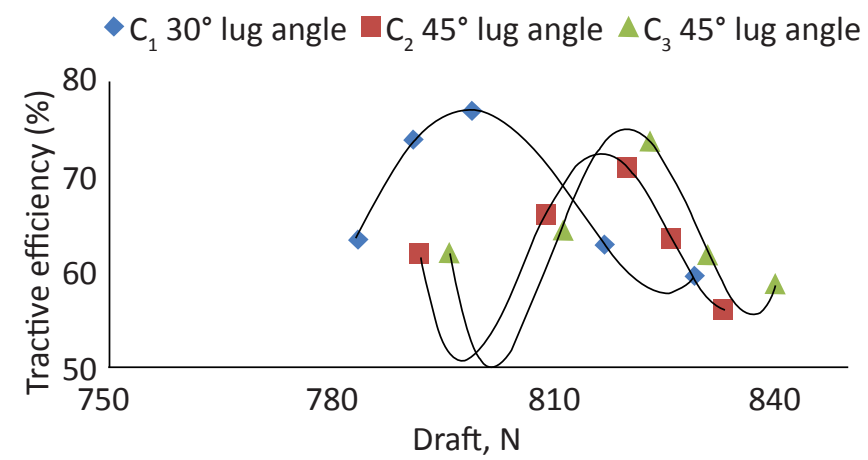

Figure 8: Effect of draft on tractive efficiency at 100 to 150 $\mathrm{mm}$ depth of water efficiency and draft increases. Minimum tractive efficiency was found $56.15 \%$ at $833 \mathrm{~N}$ draft for cage wheel $\mathrm{C}_{2}$ due to more slippage and sticking of soil Figure 8.

3.4. Effect of lug angle on drawbar power and tractive performance at 150 to $200 \mathrm{~mm}$ depth of water

The drawbar power (W) and Drawbar pull (N) of different angle of cage wheel in 50 to $100 \mathrm{~mm}$ water level $200 \mathrm{~mm}$ standing water level of different lug angle of cage wheel is presented in Table 5. The maximum drawbar power was obtained $505.26 \mathrm{~W}$ at $802 \mathrm{~N}$ draft followed by cage wheel $\mathrm{C}_{2}, 492.27 \mathrm{~W}$ at $807 \mathrm{~N}$ and $\mathrm{C}_{3} 472.70 \mathrm{~W}$ at $815 \mathrm{~N}$ draft. It was revealed that increases of standing water in wet land field condition the drawbar power requirement and draft was reduced as shown in Figure 9. Effect of lug angle of cage wheel at $150-200 \mathrm{~mm}$ of water level tractive performance presented in (Table 5). It was revealed that maximum tractive efficiency was found $73.71 \%$ at $783 \mathrm{~N}$ draft for cage wheel $\mathrm{C}_{1}$. The respective tractive efficiency for cage wheel $\mathrm{C}_{2}$ and $\mathrm{C}_{3}$ were $71.42 \%$ at $789 \mathrm{~N}$ draft and $69.51 \%$ at $785 \mathrm{~N}$ in flooded soil. Minimum efficiency

Table 5: Drawbar pull (N) of different angle of cage wheel in 150 to $200 \mathrm{~mm}$ water level

\begin{tabular}{|c|c|c|c|c|c|c|c|c|c|}
\hline \multirow{2}{*}{$\begin{array}{l}\text { Cage } \\
\text { wheel } \\
\text { Sl. No. }\end{array}$} & \multicolumn{3}{|c|}{$\mathrm{C}_{1} 30^{\circ}$ lug angle } & \multicolumn{3}{|c|}{$\mathrm{C}_{2} 45^{\circ}$ lug angle } & \multicolumn{3}{|c|}{$\mathrm{C}_{3} 60^{\circ}$ lug angle } \\
\hline & $\begin{array}{l}\text { Draft } \\
\text { (N) }\end{array}$ & $\begin{array}{c}\text { Drawbar } \\
\text { power (W) }\end{array}$ & $\begin{array}{c}\text { Tractive } \\
\text { efficiency (\%) }\end{array}$ & $\begin{array}{l}\text { Draft } \\
\text { (N) }\end{array}$ & $\begin{array}{l}\text { Drawbar } \\
\text { power (W) }\end{array}$ & $\begin{array}{c}\text { Tractive } \\
\text { efficiency (\%) }\end{array}$ & $\begin{array}{l}\text { Draft } \\
\text { (N) }\end{array}$ & $\begin{array}{l}\text { Drawbar } \\
\text { power (W) }\end{array}$ & $\begin{array}{c}\text { Tractive } \\
\text { efficiency (\%) }\end{array}$ \\
\hline 1. & 756 & 476.28 & 60.10 & 762 & 464.82 & 57.11 & 759 & 440.22 & 59.93 \\
\hline 2. & 768 & 483.28 & 68.28 & 771 & 470.31 & 62.47 & 776 & 450.08 & 63.52 \\
\hline 3. & 783 & 493.29 & 73.71 & 785 & 478.85 & 69.51 & 789 & 457.62 & 71.42 \\
\hline 4. & 793 & 499.59 & 67.19 & 796 & 485.56 & 63.69 & 801 & 464.58 & 60.93 \\
\hline 5. & 802 & 505.26 & 62.91 & 807 & 492.27 & 58.85 & 815 & 472.70 & 55.72 \\
\hline
\end{tabular}

$-C_{1} 30^{\circ}$ lug angle ${ }^{\prime} C_{2} 45^{\circ}$ lug angle $\triangle C_{3} 45^{\circ}$ lug angle

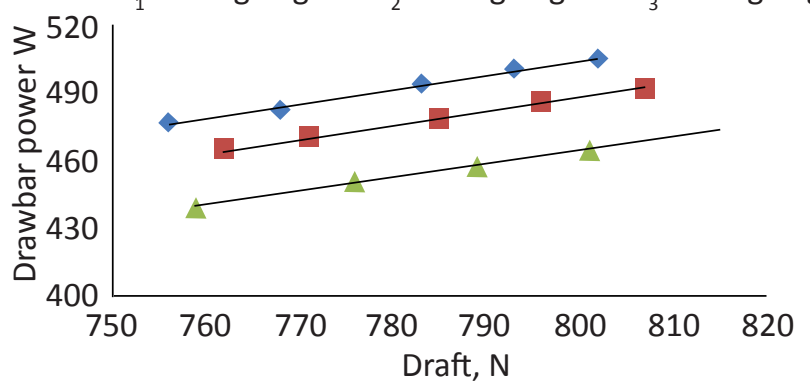

Figure 9: Effect of draft on drawbar power at 150 to $200 \mathrm{~mm}$ depth of water

was obtained $55.72 \%$ for cage wheel $\mathrm{C}_{3}$ at $815 \mathrm{~N}$ draft. It was observed that in each lug angle, increase in draft the tractive efficiency increases up to maximum on a point than it reduced as shown in Figure 10. Narang and Varshney (2006) found that the values of draft on tilled land with pneumatic wheels at engine speed of $2000 \mathrm{rpm}$ were 803 and $773 \mathrm{~N}$ in second low and third low gears, respectively.

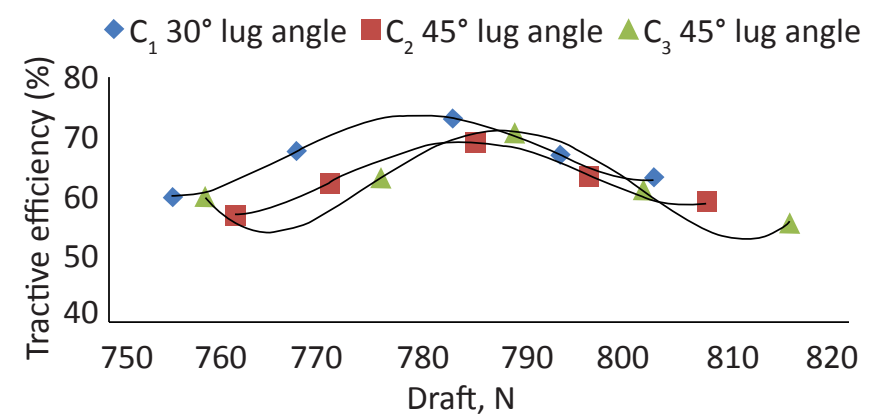

Figure 10: Effect of draft on tractive performance at 150 to $200 \mathrm{~mm}$ depth of water

\section{Conclusion}

The study showed that increasing lug angle decreasing the drawbar power and tractive efficiency. The best result was found in $30^{\circ}$ lug angle of cage wheel with min slippage, less sinkage. It was also revealed that increasing water level on field reducing the draft because of minimum soil blocking on 
the cage wheel surface.

\section{Acknowledgement}

This work was supported by the Principal Investigator, Niche Area of Excellence-Farm mechanization in Rainfed Agriculture (ICAR), Faculty of Agricultural Engineering., IGKV, and Raipur (C.G.)

\section{References}

Anonymous., 1975. Production figures of tractors and power tillers. Agricultural Engineering Today 1(1), 16.

Baloch, M.J., Mirani, B.A., Bukhari, S., 1991. Prediction of field Performance of Wheel Tractors. Agricultural Mechanization in Asia, Africa and Latin America 22(4), 21-24.

Kumar, A., Baruah, D.C., 2016. Performance of lugged cage wheel for wetland cultivation, Agricultural Engineering International: CIGR Journal 18(3), 113-118.

Pandey, K.P., Ojha, T.P., 1978. Effect of lug height on tractive performance of rigid wheels in puddled soil. Journal of Agricultural Engineering 10(5\&6), 38-43.

Abubakar, M.S., Ahmad, D. Othman, J., Sulaiman, S., 2009. Present State of Research on Development of a High Clearance Vehicle for Paddy Fields, Research Journal of Agriculture and Biological Sciences 5(4), 489-497.

Narang, S., Varshney, A.C., 2006. Draft ability of an $8.95 \mathrm{~kW}$ walking tractor on tilled land. Journal of Terramechanics
43(4), 395-409.

Salokhe, V.M., Gee-Clough, D., 1988. Cage wheel blocking in wet clay soil. Journal of Agricultural Engineering Research 39(4), 277-286.

Salokhe, V.M., Gee-Clough, D., 1988a. Coating of cage wheel lugs to reduce soil adhesion. Journal of Agricultural Engineering Research 41(3), 201-210.

Salokhe, V.M., Manzoor, S., Gee-Clough, D., 1990a. The measurement of forces on a cage wheel lug when operating in wet clay soil. Soil \& Tillage Research 14 327-340.

Singh, S., 2007. Farm machinery - Principles and applications. Directorate of Information and Publications on Agriculture, Indian council of Agricultural Research, New Delhi.

Singh, S., Singh, R.S., Singh, S.P., 2010. Farm Power Availability and Agriculture Production Scenario in India. Agricultural Engineering Today 34(1), 9-20.

Triratanasirichai, K.T., Oida, A., Masashi, H., 1990. The Performance of Cage Wheels for Small Power Tillers in Agricultural Soil. Journal of Terramechanics 27(3), 193-205.

Taufik R., Wawan H., Tineke M., Setyo P., 2014. Tractive Performance Testing of Lug Wheel in a Soil Bin, International Journal of Scientific \& Engineering Research 5(7). 